\title{
Sciendo
}

RURAL SUSTAINABILITY RESEARCH 45 (340), 2021

ISSN - 2256-0939

(c) Latvia University of Life Sciences and Technologies, all rights reserved http://www.llu.Iv/en/

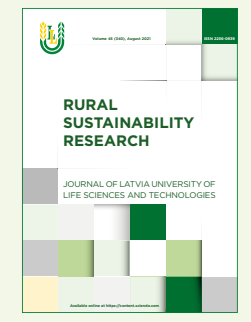

Received: 26 January 2021

Revised: 29 March 2021

Accepted: 21 June 2021

\section{The Efficiency of Different Wood Coatings against Water Surface Absorption}

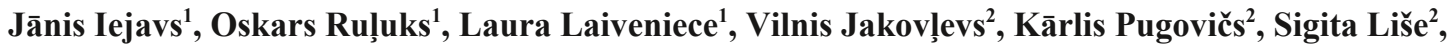 \\ ${ }^{*}$ Uldis Spulle ${ }^{2}$ \\ ${ }^{1}$ Forest and Wood Products Research and Development Institute Ltd., Dobeles street 41, Jelgava, Latvia \\ ${ }^{2}$ Latvia University of Life Sciences and Technologies, Dobeles street 41, Jelgava, Latvia
}

\begin{abstract}
In the market of the Latvia different wood surface coating materials suitable for use in outdoor conditions are offered, but available information on the efficiency of these against direct water exposure is insufficient. For structural timber building elements, such as glued laminated timber (GLT), the surface coating should be applied taking into account technological, visual or colour changes (ISO 7724:1984) and - last, but not least economic aspects are considered. Wood surfaces coated with coating materials, such as varnishes, paints, etc. can stabilize some properties such as movement of moisture content, dimensional changes and attack by microorganisms and fungi. The changes in the moisture content of timber may influence such important parameters as mechanical properties and the total life time of the structural timber elements. A study has been conducted with the aim of assessing the efficiency of coating materials used for wood protection against water absorption. In this study, six different commercial coating products used for the treatment of spruce (Picea Abies L. Karst.) and pine (Pinus Sylvestris L.) samples were tested. The efficiency of different coating substances was assessed using two modified test methods according to the standards EN 382-2 (1994) and EN 927-5 (2006), determining the surface water absorption after immersion in water for $24 \mathrm{~h}$ and the dynamics of water absorption of the glued laminated timber for $696 \mathrm{~h}$ kept in water. As a result of the study, it has been ascertained that organic solvent-based commercial coating products are more efficient against short-term and longterm wood water absorption compared to oil-based coating materials.
\end{abstract}

Keywords: construction wood, pine and spruce, heartwood and sapwood, oils, paints.

\section{Introduction}

Wood is a biodegradable material, its durability against fungi and insects is presented in the European standard EN 350 (2016) and in many researches (Alfredsen, Flate, \& Evans, 2007; Van Acker, Stevens, $\&$ Nys, 1992). This is the reason for protecting wooden materials, especially those which are used in outdoor conditions.

High water absorption capacity of wood materials influences moisture content changes in wood. Dimensional changes are not linear when the moisture content exceeds $20 \%$ and the microbiological attack is encouraged (Carll \& Wiedenhoeft, 2009). Therefore, there is a need to protect wood products for exterior uses with different coating systems that inhibit water uptake by wood. This issue is particularly pressing in construction elements, because the increasing moisture in wood can also reduce the mechanical strength of wooden structures and increase elasticity.

The production and application of glued laminated timber (GLT) for construction purposes have rapidly developed in Europe and also in Latvia over the last decade (Dubois, Verkasalo, \& Claessens, 2020; Stalidzane, 2019). These materials are mainly used as load-bearing construction elements for indoors, but are increasingly designed to be used for outdoor conditions or in service class 3 accordance EN 19951-1 (2004) and protect from the impact of the direct moisture (water, snow, ice), ultraviolet radiation and extensive fluctuations in air temperature. Thus, the issue of protecting glued structural timber against the effects of the environmental conditions has become a

\footnotetext{
* Corresponding Author's email: uldis.spulle@1lu.lv
} 
theme for deeper investigation. The most durable wood species in the Central Europe is the black locust (Robinia pseudoacacia L.) (Pollet, Jourez, \& Hebert, 2008) and in the near future it could be used with high potential for exterior use. Nowadays for building construction elements the spruce and pine structural timber (EN 338:2016) covered with different coating systems are used, and the main reason is to protect the building load-bearing constructions from direct environmental impact. Wood species with high content of tannins, wood resins and extractives have a higher natural durability and this is the basis of the eco-friendly protection of wood products as well (Huang, Maher, \& Amartey, 2004; Amusant et al., 2005; Asamoah \& Antwi-Boasiako, 2007).

The coatings with various types and chemical composition are widely used to protect timber against environmental impacts in the world. This experience of practical and knowledge-based use nowadays are vital for Latvian GLT production companies. Wood coating materials of different chemical composition may form a principally different coating system with different operating mechanism (Perera \& Selier, 1973). For example, an excessive use of surface active substances prior to the use of alkyd emulsion coating materials reduces the ability of coating material to repel water, but such an indicator as the particle size of water-based acrylic dispersion paints can significantly affect the ability of the coating material to absorb water. Water absorption capacity for alkyd emulsion paints is higher when compared, for example, with solvent-based paints and acrylic paints (Ekstedt, 2003).

Duration of the use of coating material under certain operating conditions is emphasized as one of the most significant factors which reduces the efficiency of coating materials against water exposure. Several studies analyse the efficiency of coating materials against water exposure after aging the samples in artificial conditions which provide a more complete picture of the long-term efficiency of a coating material against direct water exposure. For example, for aged wood protected with coating material, water absorption capacity increases by $30 \%$ compared to the protected wood, which has not been aged (Ekstedt, 2002).

Pine (Pinus sylvestris L.) and spruce (Picea abies L. Karst.) wood is the most widely used in the construction elements all around Europe. Comparing the biological resistance of these species to the exposure of microorganisms, it can be concluded that pine heartwood is moderately durable, while pine sapwood and spruce wood are not durable accordance EN 350 (2016). As a result, both tree species used outdoors, need to be protected against the effects of biological microorganisms.
The difference between the chemical composition of pine heartwood, sapwood and spruce wood (e.g., presence of extractives) micro and macro structure determine the different water absorption capacity of each wood species. This difference is observed not only among different tree species, but also in the coating of the same tree species, such as pine and oak between heartwood and sapwood (Olsson et al., 2001). Differences of wood structure in the radial and tangential direction of fibres also significantly affect wood water absorption capacities (Côté, 1963; Nussbaum, Sutcliffe, \& Hellgren, 1998).

This study analyses the exposure of water with coating materials, because the exposure to water makes more serious damages in wood structures compared with water vapour exposure (Ekstedt, 2002). The most common efficiency of coating materials against water exposure is considered when treating wood in radial or tangential direction (EN 927-5:2006), but this study also considers the effects of water absorption dynamics for wood end grain, since water is absorbed most rapidly in the direction of wood fibres.

\section{Materials and Methods}

Temporary water absorption of treated wood surface

The efficiency of wood coating commercial products against water absorption has been assessed using two test methods - water absorption of coated wood surfaces based on the standard EN 382-2 (1994) test method and immersion in water for 24 hours based on the standard EN 927-5 (2006) requirements.

In total 84 samples were made from conditioned pine (Pinus sylvestris L.) wood lamellas (42 heartwood and 42 sapwood pieces) and 42 samples from spruce (Picea abies L. Karst.) wood. In all cases, wood fibres were in the tangential direction against the treated plane. The nominal dimensions of the samples in all cases were the following: thickness $20 \mathrm{~mm}$, length and width $150 \mathrm{~mm}$. All samples were stored under the conditions of $65 \pm 5 \%$ and $20 \pm 2{ }^{\circ} \mathrm{C}$ up to a constant mass. The surface of the samples was planed and sanded with sandpaper \#220. Within $24 \mathrm{~h}$ after sanding, the coating, using six different commercial products, was provided. The specification of the coating products according to the manufacturers' information is given in Table 1.

For spruce, pine heartwood and sapwood additionally six uncoated samples were made to determine the reference indicators of the surface water absorption of uncoated wood. Prior to the application of the coating product, the sample area and the required total amount and consumption of the coating material were determined according to the requirements of the manufacturer. The coatings were applied in two layers using a brush or roller Table 1. The surface sanding 


\section{Description of commercial coating products according to the manufacturers' data}

\begin{tabular}{|c|c|c|c|c|c|c|}
\hline \multirow{2}{*}{ Product } & \multirow{2}{*}{ Type } & \multirow{2}{*}{$\begin{array}{l}\text { Density } \\
\left(\mathrm{kg} \cdot \mathrm{l}^{-1}\right)\end{array}$} & \multicolumn{2}{|c|}{ Consumption } & \multirow{2}{*}{$\begin{array}{l}\text { Applying } \\
\text { type }\end{array}$} & \multirow{2}{*}{$\begin{array}{l}\text { Number } \\
\text { of } \\
\text { coatings }\end{array}$} \\
\hline & & & $\left(\mathrm{m}^{2} \cdot \mathrm{l}^{-1}\right)$ & $\left(\mathrm{g} \cdot \mathrm{m}^{-2}\right)$ & & \\
\hline STAFOR Linseed oil & linseed oil & 0.95 & 8 & 118 & Brush & $1-4$ \\
\hline ADLER Pullex bodenöl & solvent based pigmented oil & 0.87 & 15 & 57 & Brush & 2 \\
\hline PROTIM & organic based pigmented oil & 0.90 & 6 & 150 & $\begin{array}{l}\text { Brush, } \\
\text { spraying }\end{array}$ & 2 \\
\hline RILAK Tekstur dekor & semi-translucent alkyd colour & 0.84 & 24 & 35 & Brush & 2 \\
\hline REMMERS HK lasur & solvent based alkyd resin & 0.87 & 4 & 200 & Brush & -3 \\
\hline STAFOR Swedish paint & solvent free natural oil & 1.00 & 5 & 200 & $\begin{array}{l}\text { Brush or } \\
\text { roller }\end{array}$ & 2 \\
\hline
\end{tabular}

between the applications of the first and second coating layer was not provided. The actual consumption of the coating product at the time of application was controlled with $0.01 \mathrm{~g}$ accuracy and the consumption of the coating product for each coating type is given in Table 2 . The application of the last layer after $24 \mathrm{~h}$ was performed and the samples were placed in the conditioning room in standard atmosphere for 7 days for complete hardening of the coating material.

The water absorption capacity was determined using the test principle of the standard EN 382-2 (1994) Figure 1.

The next testing steps involved calculation of water absorption in absolute values and percentages, according to the requirements of the standard EN 382-2 (1994) procedures.

Data processing resulted in the following statistical characteristics: the mean surface water absorption (AV) $\left(\mathrm{g} \cdot \mathrm{m}^{-2}\right)$ and water absorption $(\%)$ of the control sample water absorption A\% (\%); standard deviations of sample groups, coefficients of variation and confidence level of the mean value. For comparing the mean values of the tested groups, the Student t-test and p-value at a 95\% confidence level were used. In the following figures, the confidence levels of the mean values are given as data dispersal rates.

Table 2

\section{Consumption of the coating products on the surface of the samples}

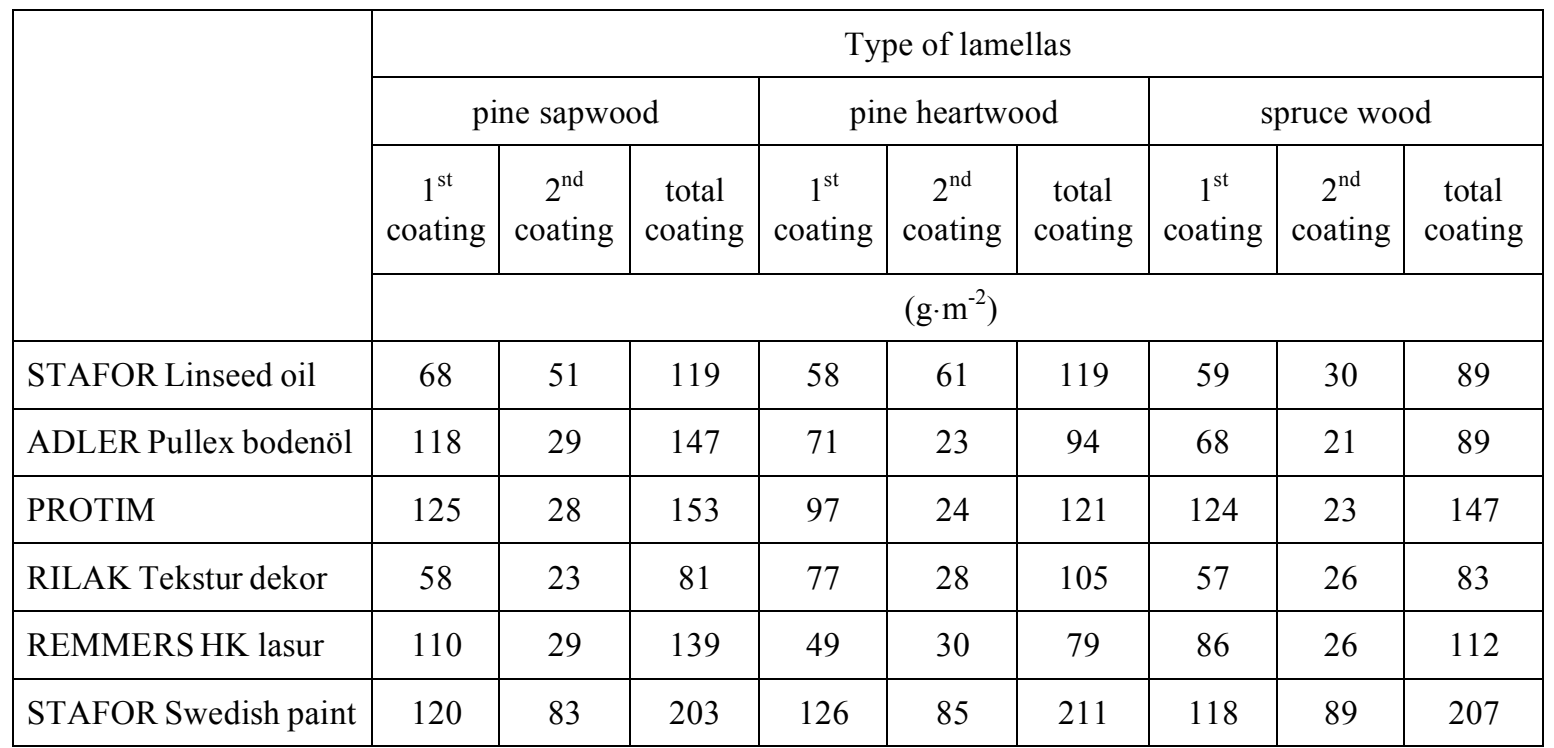



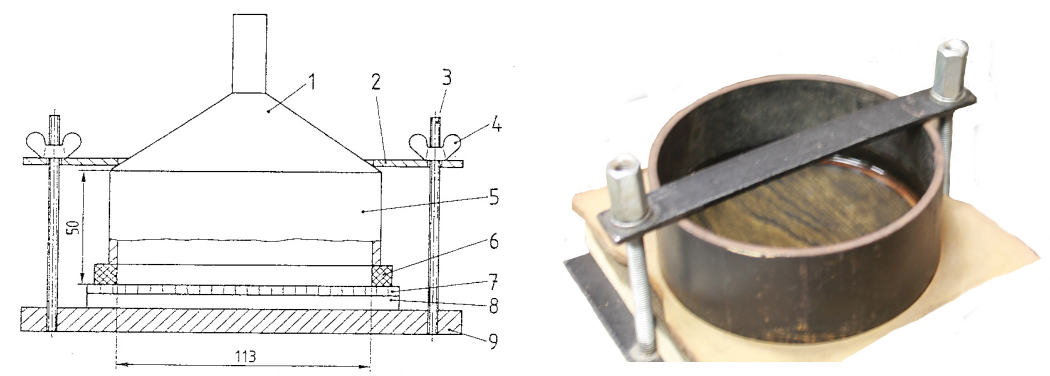

Figure 1. Test device accordance to standard EN 382-2: 1994 (on the left hand side) and laboratory device (on the right hand side):

1 - filter; 2 - clumping plate; 3 - pins with thread; 4 - clamping nuts; 5 - cylinder; 6 - rubber densely/dense rubber seal; 7 - sample; 8 - rubber; 9 - metal plate.

Water absorption of coated GLT after full immersion of samples in water

The three types of test samples used were: pine (Pinus sylvestris L.), spruce (Picea abies L. Karst.) and glued laminated timber (GLT). The GLT was made of four layer lamellas (nominal dimensions: $38 \times 128 \times 4000 \mathrm{~mm}$ and strength class C30) glued together using two-component melamine-ureaformaldehyde (MUF) glue Akzo Nobel Cascomin 1257 with a hardener of 7557 in proportion 100:50. When the surface was planed, the GLT nominal sizes were: width $125 \mathrm{~mm}$, height $130 \mathrm{~mm}$ and length 4000 $\mathrm{mm}$. For each wood species - spruce and pine, two GLT samples were made. For each wood species 21 specimens were made whose cross-sectional dimensions were equal to the cross-sectional dimensions (width $125 \mathrm{~mm}$, height $130 \mathrm{~mm}$ ) of GLT and the length of the test piece in the direction of fibres was 75 $\mathrm{mm}$ (Figure 2.), without visual wood defects (knots, splits etc.).

The total side-face area of the same sample was $0.0395 \mathrm{~m}^{2}$, while the end grain surface area was $0.0346 \mathrm{~m}^{2}$ (side-facing and end grain surface area ratio was $1.14: 1$ ). The sides of the samples were planed, the end grain surface smooth-sawn. Afterwards, the samples were conditioned at $65 \pm 5 \%, 20 \pm 2{ }^{\circ} \mathrm{C}$ to a constant mass.

For the pine and spruce GLT coating 6 types of commercial coating products were used (for description of coating materials see Table 1). For each wood species 6 sample groups were obtained -3 samples in each. A group of uncoated GLT samples was made for each wood species with 3 samples for determining water absorption rates and comparing coated GLT samples. Totally 14 sample groups were tested with a total number of samples being 42 .

Before the application of the coating material the samples were weighed and the dimensions of the samples, the surface area in $\mathrm{m}^{2}$ as well as the consumption and the amount of the required coating material for the samples were determined. Coating materials were applied using a brush or a roller. The mass of the applied coating layer was determined by a weighing method using a balance. Two coating layers were applied for both spruce and pine GLT samples. The second layer application was carried out after $24 \mathrm{~h}$. The actual amount of the applied coating material is summarised in Table 3.

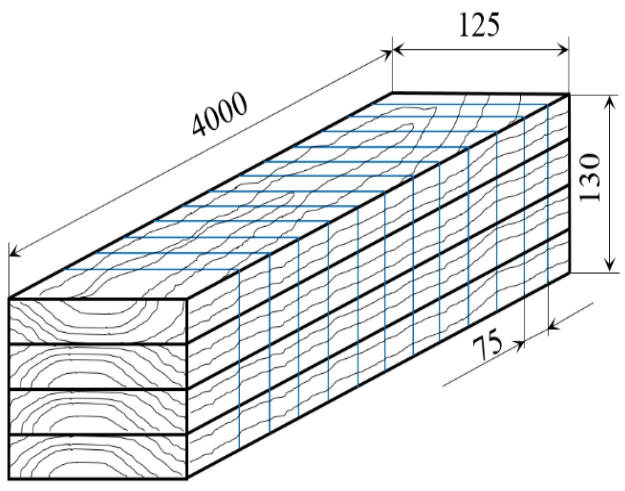

Figure 2. Specimens cutting scheme and dimensions:

dimensions - width $125 \mathrm{~mm}$, height $130 \mathrm{~mm}$, length $75 \mathrm{~mm}$; blue lines - specimens cutting lines (sawing width $4 \mathrm{~mm}$ ). 
Consumption of coating material depending on the type of the coating material and GLT

\begin{tabular}{|l|c|c|c|c|c|c|}
\hline \multirow{2}{*}{ Name of coating products } & \multicolumn{4}{|c|}{ Pine wood } & \multicolumn{3}{c|}{ Spruce wood } \\
\cline { 2 - 7 } & $\begin{array}{c}\text { end } \\
\text { edges }\end{array}$ & $\begin{array}{c}\text { side } \\
\text { edges }\end{array}$ & $\begin{array}{c}\text { total consumption } \\
\left(\mathrm{g} \cdot \mathrm{m}^{-2}\right)\end{array}$ & $\begin{array}{c}\text { end } \\
\text { edges }\end{array}$ & $\begin{array}{c}\text { side } \\
\text { edges }\end{array}$ & $\begin{array}{c}\text { total consumption } \\
\left(\mathrm{g} \cdot \mathrm{m}^{-2}\right)\end{array}$ \\
\hline STAFOR Linseed oil & 605 & 139 & 744 & 730 & 172 & 902 \\
\hline ADLER Pullex bodenöl & 482 & 77 & 559 & 467 & 74 & 541 \\
\hline PROTIM & 461 & 101 & 562 & 471 & 87 & 558 \\
\hline RILAK Tekstur dekor & 421 & 60 & 481 & 445 & 67 & 512 \\
\hline REMMERS HK lasur & 431 & 89 & 520 & 583 & 104 & 687 \\
\hline STAFOR Swedish paint & 495 & 190 & 685 & 601 & 218 & 819 \\
\hline
\end{tabular}

$24 \mathrm{~h}$ after the second coating layer, the samples were placed in the conditioning room in the standard atmosphere for 7 days for complete hardening of the coated materials. After 7 days in the standard atmosphere the samples were weighed on a balance for determining the mass. Unlike the standard EN 927-5 (2006) testing method, in this study samples with different sizes were investigated. The samples were coated on all six surfaces. The samples were placed in water (temperature $20 \pm 3{ }^{\circ} \mathrm{C}$ ). When soaking the samples, stainless steel sieves were used to separate them, thus obtaining free circulation of water around them. The investigation of the mass of samples after 24, 72 or 96 hours with nine such periods was performed. The total duration of immersion of the samples in water was $696 \mathrm{~h}$. At the end of each period, the samples were removed from the water bath, easily dried with a paper towel and weighed. After that they were reinserted into the water bath, and the cycle was continued until the end of the $9^{\text {th }}$ period.

The dynamics of water absorption for each GLT species and type of coating material was expressed as an increased mass of the samples over a certain period of time as a percentage of the starting mass of the samples. After the end of the $9^{\text {th }}$ cycle the samples were placed in a drying oven and dried in accordance with the requirements of the standard EN 13183-1 (2002) to a constant mass. The moisture content of each sample was calculated before the samples were immersed in water and after the end of the whole period of water immersion.

The study results reveal the relationships characterising the water absorption of coated and uncoated wood samples for the determination of the efficiency of coated materials. Additionally, there were curves derived for describing the moisture content changes in the samples.

\section{Results and Discussion}

The quality of the durability of the paints and varnishes as coating materials and coating systems for exterior wood elements is usually tested by a natural weathering test in conformity with the requirements of the standard EN 927-3 (2019). The influence of surface properties in different wood species on the quality of coating systems was observed also by De Windt (De Windt et al., 2014). Water absorption is one of the methods for the investigation of efficiency of wood paints and varnishes.

Water absorption rates of coated spruce and pine wood samples after immersion in water for $24 \mathrm{~h}$ are shown in Figure 3. The water absorption of the pine heartwood surface $446 \mathrm{~g} \cdot \mathrm{m}^{-2}$ is approximately four times lower than that of the pine sapwood value $1892 \mathrm{~g} \cdot \mathrm{m}^{-2}$. Meanwhile, the water absorption capacity of the spruce wood surface $\left(415 \mathrm{~g} \cdot \mathrm{m}^{-2}\right)$ is comparable to the water absorption capacity of the pine heartwood surface. The obtained indicators confirm the different pine heartwood, sapwood and spruce wood water absorption capacity mentioned in the literature (Côté, 1963).

Figure 3 shows that all the coating materials used in the study significantly reduce the water absorption of pine and spruce wood surfaces $(p<0.05)$. Comparing the efficiency of oil-based coating products (STAFOR Linseed oil, STAFOR Swedish paint, ADLER Pullex bodenöl and PROTIM) against wood water uptake with the solvent-based coating products (RILAK Tekstur dekor, REMMERS HK lasur), lower water absorption rates for pine and spruce wood are observed for solvent-based coating materials $(p<0.05)$.

Comparing the efficiency of oil-based coating material against water absorption, significantly lower water absorption capacity has been obtained by using PROTIM coating product $(\mathrm{p}<0.05)$. Regarding the 


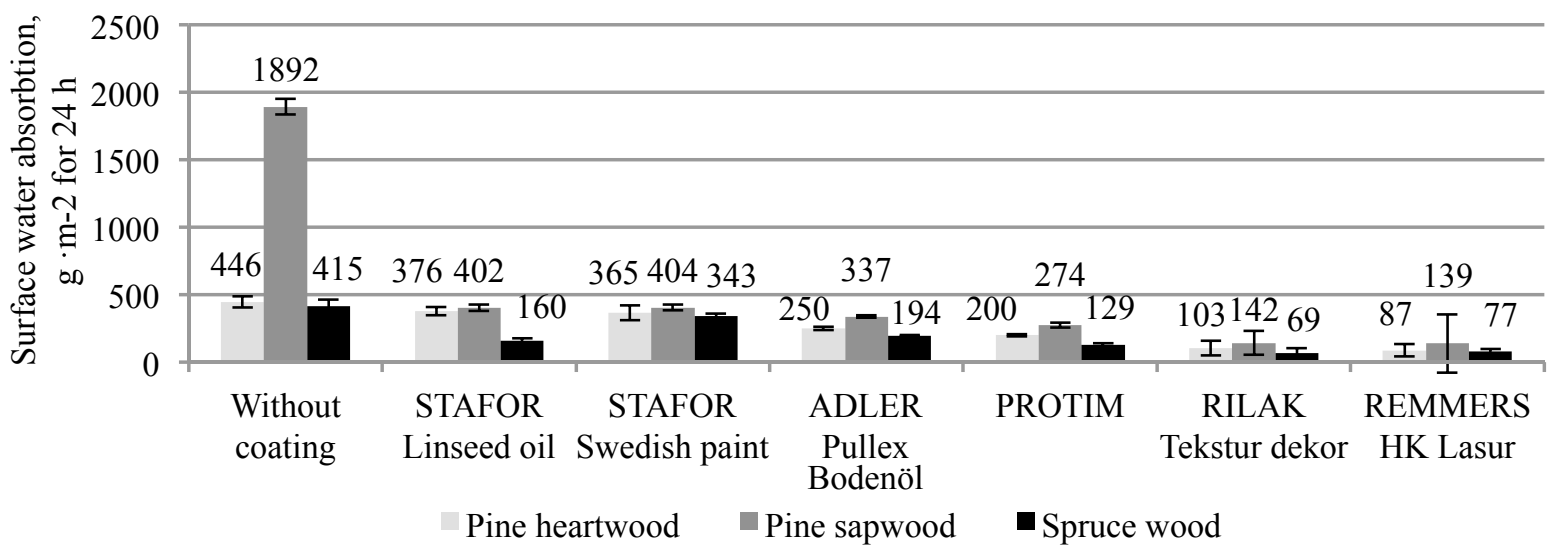

Figure 3. Water absorption of spruce and pine wood surfaces treated with coating materials after $24 \mathrm{~h}$ of water exposure.

solvent-based coating products (RILAK Tekstur dekor, REMMERS HK lasur) no significant difference in water absorption capacity was observed in any of treated wood surface types $(\mathrm{p}>0.05)$.

Water absorption capacity of spruce and pine wood surfaces treated with coating materials expressed as a percentage of the water absorption of the reference samples is shown in Figure 4. The comparison of the types of wood tangential direction surfaces (pine heartwood, pine sapwood wood and spruce wood) shows that the greatest reduction in water absorption capacity is for pine sapwood. Using oil-based coating materials, surface water absorption decreases by 79 up to $86 \%$, while for solvent-based coating materials pine sapwood surface water absorption is reduced even by up to $93 \%$. Also, pine heartwood shows a similar trend that the decrease in water absorption capacity of oil-based coating materials is smaller than in organic solvents based coating materials. Accordingly, a reduction in water absorption rates from 16 to $55 \%$ for oil-based and from 77 to $80 \%$ for organic solvent-based coating materials was observed. In spruce wood coated with oil-based coating materials water absorption capacity, after $24 \mathrm{~h}$ of water exposure, decreases by 17 to $69 \%$, while coating with organic solvent-based coating materials water absorption rates decrease by 82 to $83 \%$. The sustainability depends on the properties of timber species and the properties of coated materials - paints or varnishes.

Higher efficiency of solvent-based coating materials against the absorption of water compared to the oil-based coating materials is due to the different production principles and the ability of the material itself to absorb water (Schniewind \& Arganbright, 1984). Secondly, organic solvent-based coating materials for wood form a "film" type of coating, while coating materials on oil base do not form it.

Figure 5 shows that for both coated and uncoated pine GLT samples the water absorption capacity can be divided into two phases: the initial phase (submerging in water from 0 to $288 \mathrm{~h}$ ), in which the amount of water absorbed by the samples increases rapidly and the end phase (289 to $696 \mathrm{~h}$ ), in which the increase in the amount of absorbed water decreases significantly and the moisture equalization throughout the entire cross-section of the sample occurs. Knowing

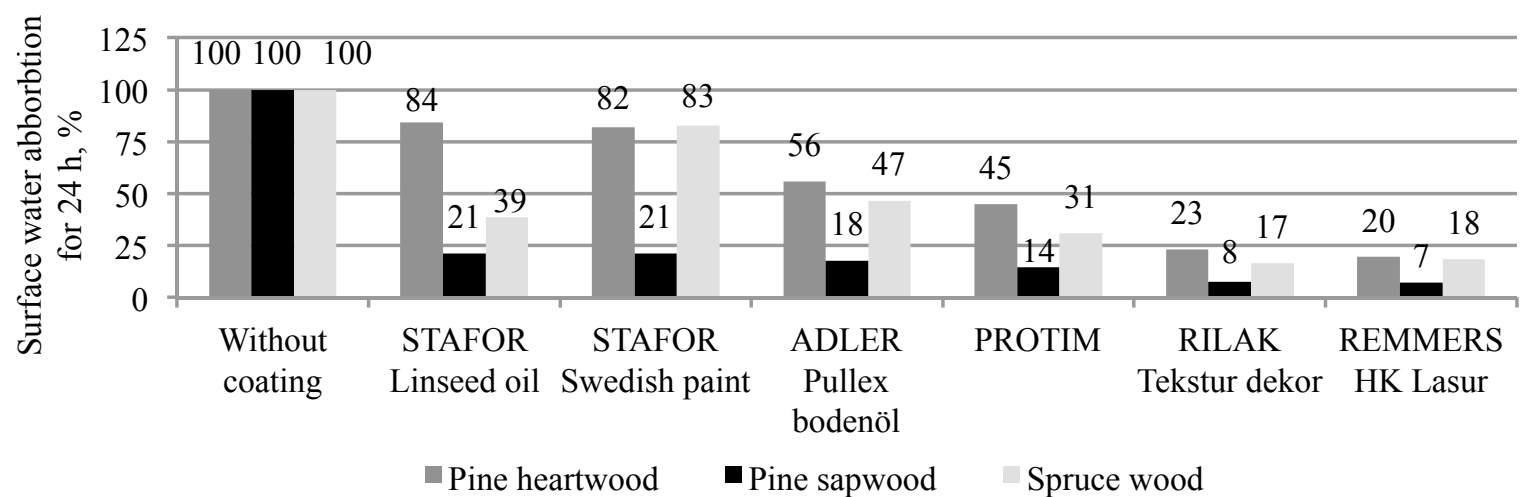

Figure 4. Water absorption of spruce and pine wood surfaces treated with coating materials expressed as a percentage of the reference samples ( $24 \mathrm{~h}$ of water exposure). 


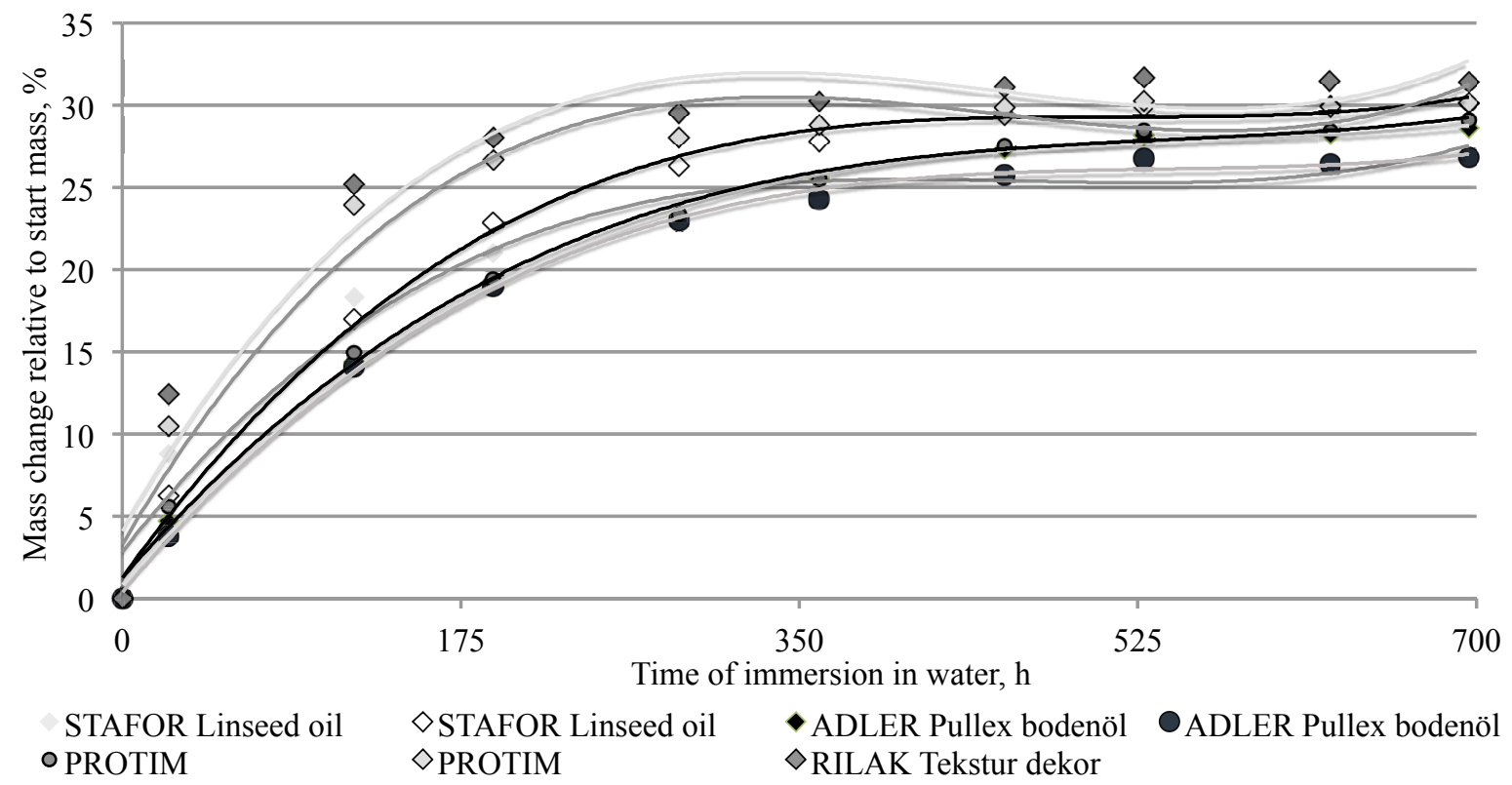

Figure 5. Changes in the mass of treated pine glued laminated timber depending on the time of sample immersion in water.

that the greatest size changes in wood occur due to wood swelling until the wood fibre saturation moisture is reached, which depending on tree species ranges from 27 to $30 \%$ (Koponen, 1985), the efficiency of wood coating material against water absorption should be assessed directly at the initial phase of moisture absorption. The quality and durability analyses of new paints under exterior conditions could give relatively exact results of their suitability for a given exposure
(Panek \& Reinprecht, 2014). After 24 h of immersion in water, most rapidly water is absorbed by uncoated pine wood samples, with a mass increase averaging $12 \%$ and an increase in wood moisture of $15 \%$ (from 14 to $30 \%$ ), Figure 6.

The highest values are for STAFOR Swedish paint: mass increase by $10 \%$ and moisture increase by $13 \%$ (from 14 to $27 \%$ ), followed by STAFOR Linseed oil with $9 \%$ increase in mass and $10 \%$ moisture gain (from

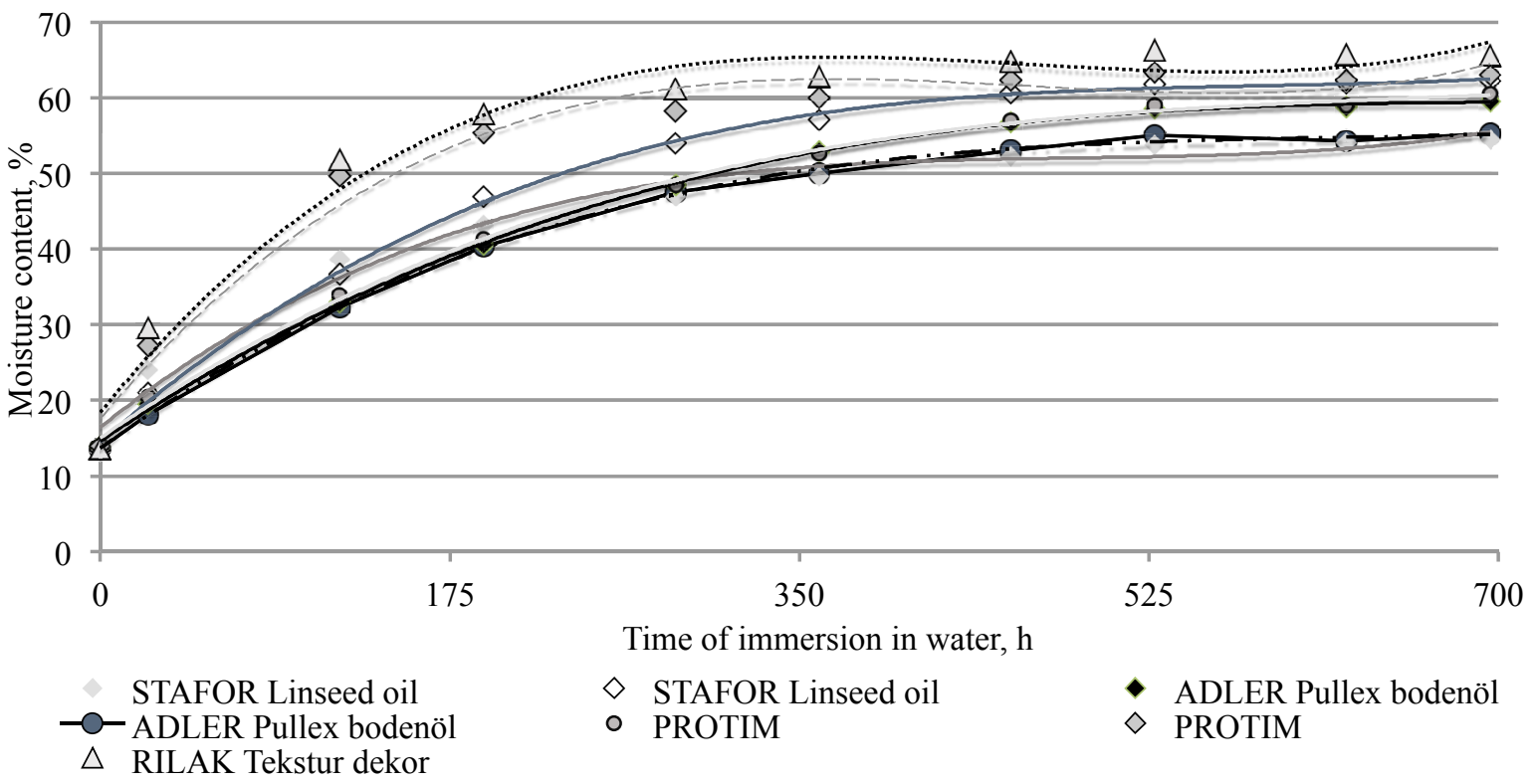

Figure 6. Changes in the moisture of treated pine glued laminated timber depending on the time of sample immersion in water. 
14 to $24 \%$ ). Ranking third regarding the efficiency of coating materials against water absorption after $24 \mathrm{~h}$ of water exposure to glued laminated timber samples, is ADLER Pullex bodenöl and REMMERS HK lasur with an average mass increase of $6 \%$ and moisture increase of $7 \%$. At the initial stage of the immersion the most effective protection against water absorption has been observed with PROTIM and the organic solvent-based coating product RILAK Tekstur dekor showing a mass increase of 5 and $4 \%$, respectively and an increase in moisture content by 6 and 4\%. Compared to the water absorption of the uncoated wood samples by absolute values, the mass increase of the samples is reduced by $17 \%$ to $67 \%$, but the moisture increase by $13 \%$ to $73 \%$.

Also, after $288 \mathrm{~h}$ in water, the average mass increment of the three samples was by $30 \%$ and the moisture increase - by $47 \%$. During this period, the lower efficiency against long-term water absorption has been observed by using STAFOR Swedish paint, with an average mass increase by $28 \%$ and moisture increase by $44 \%$, followed by ADLER Pullex bodenöl samples with $26 \%$ mass and $40 \%$ (from 14 per $54 \%$ ) of moisture gain. Similar water absorption capacity after $288 \mathrm{~h}$ of water exposure was observed for four coating product samples (STAFOR Linseed oil, PROTIM; REMMERS HK lasur and RILAK Tekstur dekor) with all four coating materials showing an average mass increase by $23 \%$ and an average increase in sample humidity by 33 to $34 \%$ reaching an average moisture content between 47 and 48\%.

The analysis of the overall trend shows that depending on the type of samples, the mass of the samples in relation to the initial mass of the samples after the immersion in water for $696 \mathrm{~h}$ had increased by 27 to $32 \%$, reaching an average sample moisture between 55 and $66 \%$.

Wood is a natural environmentally friendly material used for a wide range of non-structural and structural applications (Priadi \& Hiziroglu, 2013). The efficiency of the coating materials considered against the absorption of water by coating materials for spruce wood GLT also was analysed. Wood surfaces coated with paints or varnishes can be protected from environmental conditions such as relative humidity, attack by microorganisms or fungi and others (Kesik \& Akyildiz, 2015). The level of absorption and also moisture content of the wood are important for the long-term quality of a protective wooden surface (De Meijer \& Militz, 2001; Sonmez, Budakci, \& Bayram, 2009).

To compare the efficiency of coating materials against water absorption of coated spruce and pine wood surfaces as well as GLT all coating materials for both tests and all five sample types were ranged from 1 to 6 points, where: 1 point was given for the most efficient coating material, while 6 points for the lowest efficiency against water absorption. The most effective coating product is the one which has the lowest sum of points. The results of the ranging are summarised in Table 4.

Table 4 shows that the most efficient materials against water absorption by coating spruce and pine wood are the coating materials formed on the organic solvent base. The highest efficiency against water absorption has been reported by RILAK Tekstur dekor obtaining 12 points, REMMERS HK lasur with 16 points in the second place. PROTIM ranks the third with 21 points, STAFOR Linseed oil with 29 points ranks the fourth and ADLER Pullex bodenöl with 30 points

Table 4

\section{The efficiency of coating materials - ranging results}

\begin{tabular}{|c|c|c|c|c|c|c|c|c|}
\hline \multirow[b]{3}{*}{ Type of coating product } & \multicolumn{3}{|c|}{$\begin{array}{l}\text { Surface water absorption after } \\
\text { immersion in water for } 24 \mathrm{~h}\end{array}$} & \multicolumn{4}{|c|}{ Long-term water absorption } & \multirow[t]{3}{*}{$\begin{array}{l}\text { Total } \\
\text { score }\end{array}$} \\
\hline & \multirow{2}{*}{$\begin{array}{c}\text { pine } \\
\text { heartwood }\end{array}$} & \multirow{2}{*}{$\begin{array}{c}\text { pine } \\
\text { sapwood }\end{array}$} & \multirow{2}{*}{$\begin{array}{l}\text { spruce } \\
\text { wood }\end{array}$} & \multicolumn{2}{|c|}{ pine GLT } & \multicolumn{2}{|c|}{ spruce GLT } & \\
\hline & & & & $24 \mathrm{~h}$ & $288 \mathrm{~h}$ & $24 \mathrm{~h}$ & $288 \mathrm{~h}$ & \\
\hline STAFOR Linseed oil & 6 & 5 & 6 & 5 & 1 & 5 & 1 & 29 \\
\hline ADLER Pullex bodenöl & 4 & 4 & 4 & 4 & 5 & 4 & 5 & 30 \\
\hline PROTIM & 3 & 3 & 3 & 2 & 4 & 2 & 4 & 21 \\
\hline RILAK Tekstur dekor & 2 & 2 & 1 & 1 & 2 & 1 & 3 & 12 \\
\hline REMMERS HK lasur & 1 & 1 & 2 & 3 & 4 & 3 & 2 & 16 \\
\hline STAFOR Swedish paint & 5 & 5 & 5 & 6 & 6 & 6 & 6 & 39 \\
\hline
\end{tabular}


ranks the fifth. The lowest efficiency against pine and spruce wood water absorption has been observed for STAFOR Swedish paint which acquired 39 points.

\section{Conclusions}

1. In the tangential surface treatment process of pine and spruce wood, it has been observed that the consumption of coating material for the second coating layer compared to the first one depending on the type of coating material does not change or decrease up to $81 \%$ and the consumption of coating material decreases when treating the wood surfaces of pine trees. All coating materials used in the study significantly (by 16 to $93 \%$ ) reduced the water absorption capacity of pine and spruce wood tangential surface $(\mathrm{p}<0.05)$. The highest reduction in water absorption rates was observed in coated pine sapwood. Using oil-based coating materials surface water absorption decreases by 79 to even $86 \%$, whereas by using solvent-based coating materials, water absorption reduced by $93 \%$.

2. From oil-based coating materials significantly lower surface water absorption rates were observed by using PROTIM coating material $(\mathrm{p}<0.05)$. No significant differences in surface water absorption rates $(p>0.05)$ have been found for organic solvent-based materials (RILAK Tekstur dekor; REMMERS HK lasur). Oil-based coating materials are of lower efficiency against short-term wood surface water absorption compared to organic solvent-based coating materials.

3. The consumption of coating material for treating the end grain surfaces of glued laminated timber increased from 3 (STAFOR Swedish paint from 190 to 495 g.m-2) to 7 (RILAK Tekstur dekor from 60 to $421 \mathrm{~g} \mathrm{~m}$-2) times compared to the consumption of the material for treating the side surfaces of that wood.

4. By long-term immersion of coated spruce and pine-glued laminated timber in water, the water absorption of the glued laminated timber samples was most rapidly occurring during the first $288 \mathrm{~h}$, when the sample mass on average increased from $23 \%$ to even $34 \%$ and moisture increased from 47 to $75 \%$. In the period of 288 to $696 \mathrm{~h}$ the mass of immersed samples in water increased more slowly reaching a maximum sample moisture between 55 and $80 \%$.

5. For the glued laminated timber samples treated with oil-based coating materials, the highest water absorption capacity has been reported with STAFOR Swedish paint, while the most effective - with a lower water absorption was RILAK Tekstur dekor. Also, as a result of long-term immersion in water the materials on the oil base are of lower efficiency against the absorption through surface, compared to coating materials on the basis of organic solvents. It can be concluded that in the case of both tests of solid wood and glued laminated timber the most efficient of the coating materials considered in the study was RILAK Tekstur dekor, followed by REMMERS HK lasur, PROTIM in the third place, STAFOR Linseed oil - the fourth, ADLER Pullex bodenöl - the fifth, but STAFOR Swedish paint had the lowest efficiency against water absorption.

\section{References}

Alfredsen, G., Flate, P.O., Evans, F.G. (2007). Comparison of four methods for natural durability classification. Workshop COST Action E37, Braşov, Romania, 23 pp.

Amusant, N., Moretti, C., Richard, B., Prost, E., Nuzillard, J.M., Thevenon, M.F. (2005). Chemical compounds from Eperua falcata and Eperua grandiflora heartwood and their biological activities against wood dest roying fungus (Coriolus versicolor). IRG/WP 05-30373, 16 pp.

Asamoah, A., Antwi-Boasiako, C. (2007). Treatment of selected lesser used timber species against subterranean termites using heartwood extracts from Teak and Dahoma. IRG/WP 07-30434, 11 pp.

Carll C. and Wiedenhoeft A. C. (2009). MoistureRelated Properties of Wood and the Effects of Moisture on Wood and Wood Products. Moisture Control in Buildings: The Key Factor in Mold Prevention-2nd Edition (ed. H. Trechsel and M. Bomberg) pp. 54-79, ASTM International. West Conshohocken.

Côté, W. A. (1963). Structural factors affecting the permeability of wood. Journal of Polymer Science 2, 231-242.

De Meijer, M., Militz, H. (2001). Moisture transport in coated wood. Part 2: Influence of coating type, film thickness, wood species, temperature and moisture gradient on kinetics of sorption and dimensional change. Holz als Roh-und Werkstoff 58(6), 467-475.

De Windt, I., Van den Bulcke, J., Wuijtens, I., Coppens, H., Van Acker, J. (2014). Outdoor weathering performance parameters of exterior wood coating systems on tropical hardwood substrates. European Journal of Wood and Wood Products 72, 261-272.

Dubois H., Verkasalo E. and Claessens H. (2020). Potential of Birch (Betula pendula Roth and B. pubescens Ehrh.) for Forestry and Forest-Based Industry Sector within the Changing Climatic 
and Socio-Economic Context ofWestern Europe. Forests 336 (11), 26 pp.

Ekstedt, J. (2002). Studies on the barrier properties of exterior wood coatings. Doctoral Thesis. KTHRoyal Institute of Technology Department of Civil and Architectural Engineering Division of Building Materials. Stockholm, 63 pp.

Ekstedt, J. (2003). Influence of coating system composition on moisture dynamic performance of coated wood. Journal of Coatings Technology. 75, 27-37.

European Committee for Standardization. (2002). European standard: Moisture content of a piece of sawn timber. Determination by oven dry method. EN 13183-1. Brussels.

European Committee for Standardization. (2014). European standard: Eurocode 5: Design of timber structures - Part 1-1: General - Common rules and rules for buildings. EN 1995-1-1+A2. Brussels.

European Committee for Standardization. (2016). European standard: Structural timber. Strength classes. EN 338. Brussels.

European Committee for Standardization. (2016). European standard: Durability of wood and wood-based products. Testing and classification of the durability to biological agents of wood and wood-based materials. EN 350. Brussels.

European Committee for Standardization. (1994). European standard: Fibreboards. Determination of surface absorption. Fireboards. Determination of surface absorption. Test methods for hardboards. EN 382-2. Brussels.

European Committee for Standardization. (2019). European standard: Paints and varnishes. Coating materials and coating systems for exterior wood. Part 3: Natural weathering test. EN 927-3. Brussels.

European Committee for Standardization. (2006). European standard: Paints and varnishes Coating materials and coating systems for exterior wood. Part 5: Assessment of the liquid water permeability. EN 927-5. Brussels.

Huang, Z., Maher, K., Amartey, S.A. (2004). Effects of heartwood extractives in Dahoma (Piptadeniastrum africanum) on decay resistance to white- and brown-rot fungi. IRG/WP 04-10536, 14 pp.

International Organization for Standardization. (1984). International standard: Paints and varnishes Colorimetry. ISO 7724, Geneva.
Kesik, H.I., Akyildiz, M.H. (2015). Effect of the heat treatment on the adhesion strength of water based wood varnishes. Wood Research 60(6): 987-994.

Koponen, H. (1985). Sorption isotherms of Finnish birch, pine and spruce. Paperi ja Puu 67(2): 70-77.

Nussbaum, R. M., Sutcliffe, E. J. and Hellgren, A.C. (1998). Microautoradiographic studies of the penetration of alkyd, alkyd emulsion and linseed oil coatings into wood. Journal of Coatings Technology 70, 49-57.

Olsson, T, Megnis, M, Varna, J, Lindberg, H. (2001). Study of the transverse liquid flow paths in pine and spruce using scanning electron microscopy. Journal of Wood Science 47, 282-288.

Panek, M., Reinprecht, L. (2014). Colour stability and surface defects of naturally aged wood treated with transparent paints for exterior constructions. Wood Research 59(3), 421-430.

Perera, D.Y. Selier, P. (1973). Water transport in organic coatings. Progress in Organic Coatings 2(1), 57-80.

Pollet C. Jourez B. and Hebert J. (2008). Natural durability of black locust (Robinia pseudoacacia L.) wood grown in Wallonia, Belgium. Canadian Journal of Forest Research 38(6), 1366-1372.

Priadi, T., Hiziroglu, S. (2013). Characterization of heat treated wood species. Materials and Design. 49,575-582.

Schniewind, A.P., Arganbright, D.A. (1984). Coatings and their effect on dimensional stability of wood. 6(2), 2-5.

Sonmez, A., Budakci, M., Bayram, M. (2009). Effect of wood moisture content on adhesion of varnish coatings. Scientific Research Essay Vol. 4(12), 1432-1437.

Stalidzane K. (2019). Latvia's IKTK invests $2 \mathrm{mln}$ euro in glued laminated timber structures plant. Viewed: 04.06.2020., Available at: https:// www.baltictimes.com/latvia_s_iktk_invests_2 mln_euro_in_glued_laminated_timber_structures plant/

Van Acker, J., Stevens, M., Nys, M. (1992). Xenon simulation of natural weathering of external joinery preserving - Finishing systems. In: Proceedings 23rd annual meeting of the International Research Group on Wood Preservation. Document IRG/WP/2412-92, 13 p.

\section{Acknowledgement}

This research was carried out within the project Z44 "Glue laminated timber structures for modelling at the factory conditions" (No.3.2-10/124) co-financed by the strengthening scientific capacity at Latvia University of Life Sciences and Technologies. 